Article

\title{
Annual City Festivals as Tools for Sustainable Competitiveness: The World Port Days Rotterdam
}

\author{
Erwin van Tuij1 ${ }^{1, *}$ and Leo van den Berg ${ }^{1,2}$ \\ 1 Department of Regional, Port and Transport Economics, European Institute for Comparative Urban \\ Research (Euricur), Erasmus University Rotterdam, 3000 DR Rotterdam, Zuid-Holland, The Netherlands \\ 2 Ca' Foscari University of Venice, 30123 Venice, Italy; lvandenberg@ese.eur.nl \\ * Correspondence: vantuijl@ese.eur.nl; Tel.: +31-010-408-1186
}

Academic Editor: Peter Karl Kresl

Received: 10 January 2016; Accepted: 13 May 2016; Published: 23 May 2016

\begin{abstract}
Many cities organize annual local festivals for the positive effects on urban development, although success is far from straightforward. This article reviews a case study of the World Port Days in Rotterdam in order to demonstrate how annual city festivals can contribute to sustainable competitiveness, despite limitations as well. We show how this maritime event-that is jointly organized by the business community, the Port Authority and the City Government—offers benefits for citizens as well as for firms. Our empirical results unveil that the business value of the event includes generation of societal support, image improvement, labor market development and networking, while the value for society refers to education, leisure and to a certain degree to social inclusion. The direct value of the event for business in terms of sales and recruitment is limited, while the long-term effects of educational function deserve further attention. Finally, we provide policy lessons that, when properly contextualized, other cities may help to use annual local festivals as tools for sustainable competitiveness.
\end{abstract}

Keywords: city festivals; sustainable competitiveness; port-city; Rotterdam

JEL Classification: Q01; R00; R11

\section{Introduction}

There is a "festival fever" among cities all over the world. They do not only join the race to host one-shot external mega events, such as the World Cup Football and the European Capital of Culture (ECOC), but also invest in all kinds of annual local festivals. They do this due to many perceived advantages of hosting festivals (Richards and Palmer, 2010 [1]). Firstly, festivals are important tools in urban regeneration strategies and may contribute to tourism, image improvement and to the attraction of new foreign direct investments. Secondly, festivals are used in hypes to attract the "creative class" and to feed the "experience economy" (Linko and Silvanto, 2011 [2]). Thirdly, trade fairs, but as we argue in this article, also city festivals, are important for business development in terms of networking and access to new technologies and qualified labor (Maskell et al., 2006 [3]; Lampel and Meyer, 2008 [4]; Carvalho et al., 2012 [5]). Finally, besides economic benefits, festivals can contribute to societal development, e.g., in terms of leisure possibilities, education and training (Quinn, 2005 [6]). As such, it can be stated that festivals (or "events") are key tools for sustainable development. However, this is far from straightforward, since there are many negative effects as well, such as high (opportunity) costs, social exclusion and conflicts between visitors and inhabitants (Richards and Palmer, 2010 [1]). Additionally, events are often footloose and may move from one city to the other, challenging policy makers to strengthen the connections between cities and festivals (Van Aalst and Van Melik, 2011 [7]). 
In this paper, we explore the "World Port Days" (WPD) in Rotterdam, an annual city festival that acts as a bridge between the city and the port. The port of Rotterdam is an important contributor to the regional and even national economy. The estimated total annual value added of the port and the industrial cluster is $€ 11.6 \mathrm{~b}$ directly and indirectly $€ 7.3 \mathrm{~b}$, representing $3.2 \%$ of the Dutch GDP. It employs 87,000 people directly, and another 50,000 indirectly (Nijdam et al., 2012 [8]). On the other hand, the port and industrial cluster contributes to negative externalities in the region, including pollution, congestion and safety and security issues. Furthermore, Rotterdam is confronted with challenges that are typical for old industrial regions, including a relatively high unemployment rate, the negative image of a port city, a mismatch on the labor market (a large share of low skill workers without a job, while there is a shortage of highly educated workers) and a large multi-cultural society.

The WPD is a major instrument to counter the negative effects caused by the port and industrial activities, and as we show in this article, it plays a major role in generating sustainable competitiveness. Sustainable competitiveness is defined as "the ability of cities to keep growing and developing over time while fostering social cohesion and environmental quality" (Van den Berg et al., 2014 [9], p. 4). This refers to the capacity of cities to realize economic growth, while also taking into account the environmental and/or social pillars of sustainable development. We show that the WPD contributes to sustainable competitiveness in terms of societal development and development of value for business in particular, while environmental development turned to be less relevant, and therefore, is left outside the scope of analysis. ${ }^{1}$ We analyze how the event contributes to leisure, education, learning and social inclusion (as indicators for societal development) and to the development of business networks, labor market development, generation of societal support and image improvement (indicators for business value).

This paper is organized as follows. Section 2 briefly discusses the major concepts used in this article, being sustainable competitiveness and city festivals. Section 3 discusses the research methodology, followed by the empirical case study of the World Port Days in Rotterdam in Section 4. The final section (Section 5) concludes, provides suggestions for further research, and draws policy lessons that cities may help to use annual local festivals for sustainable competitiveness.

\section{Sustainable Competitiveness and City Festivals}

\subsection{Sustainable Competitiveness ${ }^{2}$}

The concept of sustainable development—-the first dimension of sustainable competitiveness-is widely debated, and there is no common definition (Camagni et al., 1998 [12]) and it covers different (political) perspectives (Hopwood et al., 2005 [13]). The mostly quoted definition comes from the Brundtland Report: "development that meets the needs of the present without compromising the ability of future generations to meet their own needs" (WCED, 1987 [14], p. 43). Despite a misconception suggesting that sustainable development is limited to the environment (OECD, 2008 [15]), there seems to be consensus that sustainability includes economic, social and environmental dimensions. These three dimensions (or "pillars") are integrated with each other and have different positive as well negative effects for the development of cities (Camagni et al., 1998 [12]).

Sustainable development includes many actors (e.g., national governments, enterprises, NGOs, etc.) and covers different spatial scales ranging from the local to the global level (Van den Berg et al., 2015 [16]). However, cities—the "local level"—play a key role in sustainable development.

1 In existing literature, it is stressed that it is difficult to balance economic, environmental and societal development in cities (see Section 2.1). Moreover, in various empirical case studies dealing with sustainable competitiveness (please see Carvalho et al., 2016 [12]) attention is paid to only two dimensions of sustainability, depending on the relevance of each of the pillars in the specific cases. In our case study, environmental development turned to be less relevant, and therefore, we decided to leave this dimension out of our analysis.

2 This subsection is an adapted version of a theoretical section of Van Tuijl and Van den Berg (2015) [11]. 
They are not only engines of economic growth, but also put high pressure on the environment, and are dealing with social challenges, such as social exclusion. Thus, cities are challenged to realize sustainable development, but also have the tools to do so in the form of urban development strategies. However, in reality it remains difficult to balance the different pillars of sustainable development (Carvalho et al., 2016 [10]), also depending on the political ambitions, often favoring either environmental or socio-economic development. On the contrary, in many cases unsustainable urban development takes places (Kirchberg and Sagan, 2013 [17]).

The second dimension of sustainable competitiveness is competitiveness. Competitiveness is originated in the business literature where it is used to analyze firms, but nowadays, competitiveness is also a commonly accepted construct for cities. However, how the concept is used by cities still an open debate (Carvalho et al., 2016 [10]), translated into different perspectives. A narrow view links competitiveness to clusters and has a strong economic dimension (e.g., Porter, 2000 [18]), whereas others take a broader perspective and link competitiveness also to improvement of the quality of life of its inhabitants and workers (Kresl and Ietri, 2014 [19]). From a policy perspective, the idea of competitiveness is that "cities are in competition" translated into policies aiming to attract new workers, inhabitants, companies and investments and to get a high position in all kinds of city rankings (Carvalho et al., 2016 [10]; Malecki, 2004 [20]). However, such policies may lead to "bidding wars" and are regarded as counter-productive (Rodriguez-Pose and Abrix, 2001 [21]). Therefore, it is suggested that cities need to focus on their own needs in a certain time period rather than using a strategy of "all day" following global trends (Kresl and Ietri, 2014 [19]).

In this paper, we follow the broader perspective on competitiveness, also labeled as "sustainable competitiveness". To remind the reader, sustainable competitiveness refers to "the ability of cities to keep growing and developing over time while fostering social cohesion and environmental quality" (Van den Berg et al., 2014 [9], p. 4). This concept is grounded in general urban management literature dealing with governance, the interaction between different stakeholders and urban development (e.g., Van den Berg et al., 1997 [22]). It covers various dimensions of sustainable development (economy, society and environment) and can be linked with literature exploring how firms and public authorities jointly search for new development options or tackle common challenges (Porter and Kramer, 2011 [23]; Van den Berg et al., 2015 [16]).

In Section 4, we analyze how a city festival, that is jointly is organized by the business society in the port of Rotterdam and public authorities, may function as a tool to generate sustainable competitiveness, but first, we provide a brief overview of literature on city festivals.

\subsection{City Festivals}

City festivals and trade fairs - jointly labeled as "events" — have been widely discussed in many research fields, such as urban studies (e.g., Quinn, 2005 [6]; Garcia, 2005 [24]; Gotham, 2011 [25]; Van Aalst and Melik, 2011 [7]), geography (e.g., Maskell et al., 2006 [3]; Bathelt and Schuldt, 2008 [26]; Power and Jansson, 2008 [27]) and business and organizational studies (e.g., Borghini et al., 2006 [28]; Lampel and Meyer, 2008 [4]) and cover a wide variety of topics, such as impact analysis and legacies, social inclusion, urban regeneration, and business networking. Due to this variety, literature lacks a common definition and there are various types of events. It goes beyond the purpose of this paper to discuss the various approaches into more detail ${ }^{3}$, but we briefly discuss a number of dimensions of events in order to make our argument that city festivals can contribute to sustainable competitiveness, but with limitations as well.

A first dimension refers to the degree to which events are "tied" to a specific place, conceptualized as "placeless" versus "place-bound" events (Van Aalst and Melik, 2011 [7]). Placeless events have limited to no connections to a certain place and are hosted in another place each edition and "travel

3 Please see Richards and Palmer (2010) [1] and Carvalho et al., (2012) [5] for more detailed literature reviews on urban events. 
around" the globe. Examples include the Olympic Games, the World Cup Football and the European Capital of Culture. One the other extreme, place-bound events are strongly embedded in a certain place due to factors like a "joint history", a common theme, or the organizers come from the region, and therefore, each edition is organized in the same place, such as the Oktoberfest in Munich and the finish of the Tour de France in Paris. Somewhere in between these extreme types, there are events that are part of a "global circuit", such as trade fairs, design weeks, fashion shows and certain sport competitions like the F1 car race (Power and Jansson, 2008 [27]). These events are organized in the same places each edition, but cover different shows within each time period.

Other dimensions include the size and exposure of events. One the one side, so-called "mega events" (Roche, 1994 [29]) are characterized by a high (tourist) demand and large global media exposure, while on the other side, small local events are characterized by a low demand, small media coverage and generate limited economic value (Getz, 2008 [30]).

Furthermore, events differ in scope and purpose, ranging from cultural celebrations to sport events, and from historical milestones to art events (Getz, 2008 [30]). Events can be also be targeted to leisure visitors or to business visitors, having different impacts on urban development (Carvalho et al., 2012 [5]). Leisure visitors search for spectacle and entertainment, and thus visit events for recreational purposes. This is widely discussed in urban studies literature on mega events (e.g., Garcia, 2005 [24]; Gotham, 2011 [25]) or on city festivals (e.g., Quinn, 2005 [6]; Van Aalst and Melik, 2011 [7]) and it is shown that such events have especially impact on societal development, such as social exclusion, economic development linked with the entertainment and tourism sectors, or urban generation in general. Events for business visitors, such as trade fairs and congresses, are discussed in literature in economic geography (Maskell et al., 2006 [3]; Power and Johansson, 2008 [27]; Bathelt and Schuldt, 2008 [26]) and business studies (Borghini et al., 2006 [28]; Lampel and Meyer, 2008 [4]). These studies stress the economic value of events for businesses in terms of networking, sales, recruitment of new staff, and access to new technologies and innovation.

As we illustrate with the case of the World Port Days (WPD) in Rotterdam in Section 4, city festivals can contribute to sustainable competitiveness, generating value for society as well as for business, but also with some limitations. First, we discuss research methodology in the next section.

\section{Research Methodology}

This paper is based on a diverse array of primary and secondary data sources and is part of a larger comparative study on the role of events for urban development (see Carvalho et al., 2012 [5]). We have selected the WPD as case study for our analysis for a number of reasons. First of all, the WPD is targeted to citizens, while the participants consist of firms in the port and industrial cluster (in addition to educational institutes and authorities), suggesting value for society as well as for business. Moreover, and in contrast to other city festivals, like art festivals (e.g., Quinn, 2005 [6]; Linko and Silvanto, 2011 [2]) and food or beverage festivals, the WPD does not deal with consumer products-the participating firms are active in business-to-business networks-suggesting other business benefits of the festival than sales. Secondly, the festival is jointly organized by the City Government, the Port Authority Rotterdam ("Port Authority" in brief) and the business community ${ }^{4}$, representing different stakeholders in the city. Therefore, it can be expected that the festival generates value for business as well as for citizens. Thirdly, the WPD is a well-established modern annual city festival — the first edition dates back to the 1970s - suggesting long term benefits for the various involved stakeholders.

The article draws on 18 in-depth interviews with the organizers of the event ( 2 interviews), sponsors (5) and participants (11). The sponsors of the event include representatives of the City Government as well as the Port Authority, hence representing citizens and the business society.

4 Another organizer is the Royal Navy. This is caused by a merger between the World Port Days and a Navy Festival in order to increase efficiency of resources. 
Regarding the participants, we selected a diversity of interview partners, representing firms in the port (covering various sectors, including chemicals, dredging, containers and automotive logistics), the tourism sector (1 interview), educational and research institutes (2), cultural institutes (2) and service providers for the festival (2). We purposely selected a wide diversity of interview partners to reduce bias and in order to get insights into the values for business (e.g., the participating firms and the Port Authority) as well as for society (e.g., educational institutes, City Government and cultural institutes).

The interviews were semi-structured and lasted between 1 and $2 \mathrm{~h}$. Interviewees were asked about their ratio for participating the event; how they participate (organization of an excursion, participation in the exhibitor market/fair, or providing a demonstration, see Section 4.1); what they do during, before and after the event; their ambitions and results of participation; changes in time, visitors and target groups; general opinion about the event; organization and communication of the event; and comparison with other events. The interview topics cover social development (indicated with leisure, education, learning and social inclusion) and business development (development of networks, access to new innovation/technology, labor market development, image improvement and generation of societal support).

In addition to the interviews, the article benefited from two moments of participant observation carried out during an ethnographic-like field trip during the event, and a round table meeting (with representatives of the Port Authority, the City Government and participants of the festival discussing a new strategy for the festival). The moments were used to gain deeper insights about the festival and the possible contribution to sustainable competitiveness and limitations. The field trip was also used for short "on-site" interviews with participants (lasting between 3 and $15 \mathrm{~min}$ ), largely targeting to the ratio and way of participating. Finally, the primary research data were coded and triangulated with secondary sources, like scientific publications, press releases, corporate reports, policy documents, industrial magazines and information from multiple companies' websites.

\section{World Port Days and Sustainable Competitiveness}

In this section, we explain the value of the World Port Days (WPD) for society and business by analyzing the visitors (Section 4.2) and participants (Section 4.3), but first we provide a general background of this maritime spectacle (Section 4.1).

\subsection{General Description of the World Port Days}

The WPD is a place-bound event that is strongly connected to the port-city of Rotterdam as it deals with the city's major economic pillar; it is organized by local stakeholders; and it is targeted to visitors from the region in the first place. The maritime spectacle was initiated by an employee of the Port Authority in 1977 as a response to the relocation of port activities away from the city towards the sea. This relocation was caused by containerization, changes in maritime trade, increasing size of ships and negative effects of port and industrial activities in urban areas. As a consequence, the port was (and still is) moving westwards to the sea and the citizens were losing track of what was going on in the port. Moreover, the port became increasingly connected with negative images and perceptions (pollution, congestion, unemployment, etc.). Thus, the event was set up as a way to counter the negative effects and make the citizens "smell and bound" with the port again.

During the first period, 1977-1991, the WPD was an open harbor day with the mission to show the port to the citizens. Its concrete location (within the port) varied through the years. The main activities included "watching ships" and excursions to firms in the port. The organization of the event was simple and done in an informal way by the Port Authority in cooperation with some major entrepreneurs from the port who provided services for the visitors, such as boat trips or guided tours at port and industrial sites (e.g., on container terminals and oil refineries). In that time, the so-called "port community" was a small and informal network and it was easy to arrange the event with support of the members of the community. 
In the 1990s, the organization of the event changed and the event was transformed from a one-day event to a large three-day spectacle. Other actors got involved in the organization of the event, including the City Government that was interested in the event for the economic potential and tourism development. In addition, many new companies and partners joined the event. Concerning the location, the WPD moved its core to the waterfront in the city center, where it is more accessible for visitors and close to the main office of the Port Authority. Its main concept (lasting until now) involved: (i) showcasing port activities and companies at an exhibition (or "fair") in the city center; (ii) demonstrations and port-related shows on the river in the city center; and (iii) excursions to firms and major institutes in the port.

Nowadays, the WPD is a large maritime spectacle with a large number of participants and visitors and combining various activities (see Table 1). Despite the changes in the 1990s, the original ratio for hosting the event has remained the same, a platform to show the port to society. As we explain in the remainder of this section, the event contributes to sustainable competitiveness, generating value for citizens (Section 4.2) and for firms (Section 4.3), but with some important limitations as well.

Table 1. Basic data World Port Days (WPD).

\begin{tabular}{ll}
\hline Visitor number & 400,000 \\
\hline Origin of visitors (based on excursion tickets sold) & $50 \%$ from region; $45 \%$; rest of The Netherlands; 5 from abroad \\
\hline Organizers & Port Authority, City of Rotterdam, Royal Navy \\
\hline Media coverage & Regional to national \\
\hline Participants & Firms, authorities, educational institutes, cultural organizations \\
\hline Activities & Excursions to the port, exhibition/fair in city center, demonstrations \\
\hline
\end{tabular}

\subsection{Visitors and Societal Value}

The WPD is among the most successful events of Rotterdam in terms of visitor numbers. It is, with about 400,000 visitors, one of the largest annual events; it has the strongest brand name among regional festivals; and is the mostly visited event among inhabitants (Van der Wilt, 2011 [31]; Reijnen, 2011 [32]). The popularity of the festival was also mentioned in the interviews; for instance, as put forward by a participating firm who compared the WPD with one of the most popular annual festivals in The Netherlands: "The WPD is the Queens day of Rotterdam. Amsterdam has Queens's day and Rotterdam the WPD". But who visits the WPD and what is the impact of the event on the society?

The largest visitor group is the "general public", being families who visit the event for leisure reasons. This was confirmed by the organizers, sponsors and participants. For instance, as illustratively quoted by a service provider of the event: "Even though there is another theme (each year), the idea is still the same: the WHD is a simple party for families." The majority of the visitors come from the region. For instance, using the booked excursions as an indicator, about $50 \%$ of the visitors come from the region, $45 \%$ from the rest of The Netherlands, while 5\% comes from abroad (interview data). The latter two segments have gradually increased during the last years, and the introduction of excursions in English seems to be a success as all the English excursions organized are fully booked.

Apart from a leisure function, the WPD has an important role to explain visitors the role of the port in the society. The idea of the organizers and participants is to increase citizen's understanding about negative externalities caused by port activities and to get societal support for large infrastructural projects, such as Maasvlakte II (an extension of the port on newly reclaimed land from the sea) and the Betuwelijn (a rail line dedicated to freight transport only). Thus, the event has a major educational role, and via excursions and demonstrations, the organizers and participants try to demonstrate visitors 
the function of the port and its value in the daily life $e^{5}$. For instance, Shell organizes an excursion that includes a field visit on its site in Pernis as well as a presentation explaining the refinery process. Another example is container terminal operator RWG that organizes a simulation game for youths in which they build the company's logo with boxes, not only targeting to have pleasure but also to explain how container handling works. Likewise, Van Oord allows visitors to access a large dredging vessel to show the audience what the dredging sector is about. To do so, it asks a balanced mix of its staff (e.g., Human Relations, marketing and communication, hydraulic engineers and sonar technology specialists) to volunteer as a guide on the vessel during the event in order to give a more representative idea about the various disciplines working in this sector.

Even though the (long term) effects of such activities might be questionable, the importance of the educational role has also been highlighted by the cooperation the organizer has with educational institutes and the organization of specific programs for kids and students. One example is Kids Day, on which school classes visit the WPD in order to get a glance about the port function. To increase the interest of kids and youths, the organizers and the schools entertain kids and let them play, for instance, via puzzle tours and simulation games. Another example is a seminar organized by a local university and the organizers of the event. The seminar deals with contemporary issues in the port and is targeted to bachelor and master students who may be interested to work in the port in the near future. A third example is the so-called "World Port Hackathon", a side-event organized during the WPD. During this hackathon, the organizers (Port Authority, various firms in the port and research institutes) do not only search concrete solutions for actual challenges the port is facing, but the event also provides participants insights about these challenges, and the databases and technology used in the port.

In addition to families, youths and kids, the WPD plays a role for seniors. As mentioned by an exhibiting educational institute about the visitors: "it is mainly a fair for families and harbour freaks, including old port employees...Some simply visit the fair because of the good weather". This quote does not only illustrate the leisure function, but also hints to the social inclusion of seniors. Various interview partners explained that many former port workers visit the event to meet old friends, to see how the port has changed and to tell stories about the past. Some of these former workers have an active role and work as a voluntary tour guide during excursions. There are also specific (side) events organized for seniors, such as the "international shanty festival", a singing contest on traditional sailor songs, performed by orchestras from various places across the world. This does not only contribute to the maritime atmosphere during the event, but also functions as a day out for the-largely senior-participants.

Despite the large number of visitors and the major contribution of the event to certain parts of the society, some target groups are currently underrepresented. The WPD is regarded as the most "white event" of the city, and therefore, the organizer tries to attract more immigrants to the show. Another new target group includes expats and foreign tourists. The organizer tries to attract this group by the use of communication and promotional material in English as well via the organization of excursions in English.

In sum, the event has a societal value in three ways. It is important for leisure, education and social inclusion (e.g., of seniors), although certain groups are still underrepresented.

5 Various activities are targeted to inform visitors about environmental development in the port and industrial cluster (e.g., excursions to green spaces in the port area, lectures about strategies for countering air pollution, information about nature compensation projects, etc.). These activities could be categorized under the pillar of environmental development. However, as the event's focus is on informing citizens about these issues, and the WPD in itself does not contribute to environmental development, we decided to categorize such activities under the categories of social and business value of the event. 


\subsection{Participants and Business Value}

This section aims to explore the business value of the event. Therefore, we firstly discusses which types of firms do (not) participate in the WPD, and secondly, their ratio for (not) joining this maritime spectacle.

The event offers a wide variety of participants that may give visitors a good representation of the port and industrial cluster, despite some major exceptions. Table 2 provides an overview of the excursions (organized by the Port Authority, firms in the port and cultural institutes in the city) in different categories. The categories seem indeed to represent a large part of the port and industrial cluster-in addition city trips and culture-although our interview partners also noted that two important "cluster members" are not present during the event, being shipping lines and forwarders. Using the participants of exhibitions and demonstrations as another indicator, as not all firms organize an excursions, there seems to be a large variety as well. It is estimated in our interviews that about $50 \%$ of the participants are port related. The other half consists of participants that fit in the broader maritime theme - such as the "Navy and lifeguards" — and can indirectly be linked with the port and industrial cluster, but it also includes actors that are directly targeted to consumers, such as (small) food and drink retailers and general media. Hereby, our interview partners noted that some large food producers do not participate, despite their focus on consumers, and in contrast to other firms in the port that are mainly operating in business-to-business markets. As stressed by a manager of the Port Authority involved in the organization of the event: "We have approached Unilever many times, but they are not willing to participate.... Also other major firms in the food sector, such as Verstegen and some fruit terminals do not join, even though the theme of the 2011 edition was flavour, directly referring to food". Likewise, it was mentioned that large retailers of consumer products (like Ikea and Nike) do not join the event either.

Table 2. Excursions during the WPD 2013.

\begin{tabular}{cc}
\hline Category & Number of Excursions \\
\hline Containers & 6 \\
Food and dry bulk & 6 \\
(Petro-) chemical & 7 \\
Port development & 4 \\
Offshore and shipbuilding & 4 \\
General transport and logistics & 4 \\
Traffic control, infrastructure and other port services & 7 \\
General port tours and boat trips & 12 \\
City trips and culture & 12 \\
\hline
\end{tabular}

Source: Own elaboration—data from fieldwork; categories made by authors.

Moreover, and despite a large number of loyal participants who join the event since the first day, our interviews with the organizers made clear that it is not only a challenge to find new participants, but also for existing participants it is less straightforward to join. Whereas firms in the past participated as a sort of hobby or to give a present to society ("cocktail giving"), now they join for strategic issues, such as keeping a good relation with the Port Authority. Moreover, it was indicated that many firms have been bought by foreign firms and decisions are taken by headquarters abroad, who are less involved and interested in local development in Rotterdam. ${ }^{6}$ The participation of firms from the region has also become more uncertain, and the way participants join differs often per year depending on market dynamics and the performance of firms. It was explained in the interviews that the opportunity

6 For example, Nijdam (2009) [33] estimates that one-third of the assets in the port of Rotterdam is controlled by foreign actors. 
costs for the use of equipment during the event are high ${ }^{7}$, and many markets of firms in the port are highly dynamic, making long term, or even medium term planning of the event difficult. Likewise, external happenings may even influence participating last minute. For example, the Russian Navy was supposed to exhibit a vessel during the WPD in 2013, but cancelled this as a consequence of political tensions between the Dutch and Russian governments. Another example given in the interviews was TLR International Laboratories, a food and seed safety lab that that takes samples of products handled in the port. This lab showed interested to participate in the 2011 edition (theme "flavour"), but could not join due to a lack of capacity (staff and equipment) as a consequence of the outbreak of the EHEC bacterium ${ }^{8}$.

Hence, there is diversity in participants, with also major exceptions, such as major firms dealing with consumer products, and a general challenge that participation is less straightforward compared to the past. This brings us to the second part of this section, the ratio for (not) participating the event.

Our analysis reveals a number of reasons why firms do participate, as well as limitations. Firstly, and in line with the original ratio of the WPD, firms participate to show society what they are doing, and confirm the need to show where the port is about in order to safeguard their license to operate. This is especially the case for firms in the (petro-) chemical industry, which are often associated with negative externalities, including pollution and safety issues. To counter these negative associations and to explain the relevance of chemicals in the daily life (e.g., as input for other industries, such as automotive or food), many chemical firms participate in the WPD, e.g., via excursions (see also Table 2). Firms in other sectors also stated participating for image purposes and to show their activities to society, for instance as becomes clear with an interview with dredging company Van Oord: "We are a Rotterdam based company, and we need to be present...Our sector is relatively unknown, so we use the festival to promote the sector, to show visitors what we are doing."

This quotation does not only illustrate the "image argument", but also hints to a second reason to participate; that is firms go to the event as they are expected to do so as a "member of the port community". Various other interviewees, hereby, explicitly referred to a local community feeling, such as "We have to be here, we are a Rotterdam based company" (interview RWG) and "We participate for many years, for about 20 years or even from the beginning...we belong to the event" (STC Group). Some non-Rotterdam based companies also stressed the need to join the event to get in touch with the port community, such as the Tideway, a dredging company based in Breda.

More general, various participants stressed that it is important to go to the event to keep a good relation with the landlord - the Port Authority-and for network reasons, although the opinions regarding the latter differ. The event is particularly important for lobby purposes and for maintaining networks, while the value of the event as a formal business-to-business (B2B) platform is more complex and debated. On the one hand, various interviewees indicated that they use the event for network purposes. For instance, Verwater (a contractor in industrial installations) indicated to invite clients and their families to come the event. The main sponsor, the Port Authority, also invites strategic relations and foreign delegations to the WPD. Worth noting here is a delegation from the Port Authority of Busan, who visited the WPD not only for business reasons, but also to learn how to set up such an event for society. Various other interview partners mentioned that the event is a good occasion "to meet friends" and to "see familiar faces".

Important for such "meetings" is a strategic location at the fair. For instance, educational institute STC Group has a booth next to some large firms that are major partners of the school. Likewise, compared to the past, Cargotech (a port equipment supplier) rents a booth in a more central location of the fair. The company does not only do this to receive more visitors, but also to be closer to major firms

7 For example, a ship that is shown to the public during the WPD cannot be used for operational purposes at the same time, meaning a loss of income.

8 EHEC stands for "Enterohaemorrhagic Escherichia coli", a bacterium that causes foodborne diseases. 
in the cluster. Even though such "temporary proximity" is not used for strategic meetings, various exhibitors indicated to have chats with neighbors and to stay in touch with peers.

On the other hand, various interview partners stressed that the WPD is mainly to explain the role of the port to society, while commercial activities and networking are done at other events. This is also illustratively put forward by an organizer of the event: "Participation of the event does not generate more cargo". Many firms confirmed that the event is not used for sales purposes and B2B purposes. A cause for the limitation of the event as a possible B2B platform mentioned in the interviews is the heterogeneity of the port and industrial cluster. For example, firms from the petro-chemical industry have other interests than ones in the offshore industry and meeting each other at a B2B platform during the WPD may have limited value.

A final reason for participation is recruitment and labor market development. Various participants and the organizers use the event to show the port as a challenging work environment for skilled workers with smart technologies rather than a dull place where blue collar workers move boxes. In this sense, the WPD is supposed to function as a tool to tackle the labor shortage, also regarding the aging problem many firms are facing in the near future. Various companies explicitly stressed that they joined the WPD for recruitment purposes, like branch organization Transport and Logistics Netherlands (TLN) that rented a booth at the exhibition market as they are in an "urgent need to find new workers" for the firms they represent. Likewise, Broekman Logistics joined the event in 2005 in a time of large growth, challenging the company to fulfill vacancies. Another example is the new container terminal operator RWG that joined the WPD in 2012. This company's ratio to participate was not only to show themselves as a new player in the "Rotterdam port community", but also to find new staff to work on its site (opened in 2014).

However, at the first sight, the result of the event for recruitment purposes might be disappointing as various interview partners stressed their doubts, such as "This is not the place to find new students...We had only two persons who seriously asked about possibilities to study at our institute." and "The visitors are mainly families, we have very basic chats with them. They say something like my neighbour used to work as a 'boatsman', but we never have an in-depth conversation" (Boatsman association KRVE). Both quotes illustrate the argument that the "wrong" visitors go to the event (e.g., families and seniors instead of youths), which was also mentioned in other interviews. Nevertheless, is was also explained by various interview partners that the event has a long term and indirect effect on recruitment, like: "We hope people promote our company via mouth-to-mouth advertising, we hope people speak about us at birthdays" (Van Oord) and "The challenge is to give people a positive feeling about our firm and to improve our image. Not only among potential employers, but also among families who can be messengers to the right target group" (Broekman). Hence, the image effect is important for labor market development and recruitment on the long run, and various interview partners indicated that kids who visit the WPD today can be interested to work in the port in the future. Moreover, the different views regarding the value of the event for recruitment purposes might again be explained by cluster heterogeneity, as the labor market dynamics in the different sectors might not be equal and the individual firms may use different recruitment strategies.

In sum, even though the WPD might have limited direct value business in terms of sales and development of new networks, it has indirect and long term value for firms in terms of labor market development and to obtain and keep societal support. Moreover, it has value in maintaining networks, in particularly with the Port Authority.

\section{Conclusions and Lessons}

This article has reviewed a case study of the World Port Days (WPD) in Rotterdam in order to provide insights into the role of annual city festivals as tools for sustainable competitiveness, but with some clear limitations as well. It shows how annual local festivals, rather than one-shot external mega events, generate value for society as well the business community. The societal value of the event concerns leisure and educational functions in particular, and to a certain degree to social inclusion of 
seniors. The educational function refers to explaining citizens the port function, the involved players, and the value of the port function in daily life. This is realized by various activities organized by the Port Authority, the City Government and the business community in cooperation with educational institutes, although the long term effects of such activities are not measured. Therefore, measuring the long term impact of the WPD is put as a suggestion for further research.

The business value is largely indirect and generated on the long run, and concerns particularly obtaining societal support, promotion of sectors, labor market development, maintenance of business networks (i.e., "to keep the port community alive") and lobby purposes. The direct business value of the WPD-i.e., as a B2B platform and for direct recruitment-seems to be limited due to among others the heterogeneity of the port and industrial cluster.

Our study unveils some other results that increase our understanding of city festivals and sustainable competitiveness. First of all, we show how annual city festivals are used for image improvement purposes. The WPD is organized in order to improve the image of the port and industrial cluster among citizens. This complements the mega events literature that shows that events are used for external image building (e.g., Garcia, 2005 [24]). Secondly, in addition to other studies on events stressing the importance of festivals to create experiences (Gotham, 2002 [34]; Richards and Palmer, 2010 [1]; Linko and Silvanto, 2011 [2], Johansson and Kociatkiewicz, 2011 [35]), we show that festivals can be used for education purposes as well. Thirdly, in line with the "temporary cluster literature" (e.g., Maskell et al., 2006 [3], Bathelt and Schuldt, 2008 [26]), we have found that participants join the event due to "the need to be there temporary", as a response to pressure from clients, or in the case of the WPD, pressure from the landlord. Likewise, we have shown more empirical evidence for the importance of a strategic position of exhibitors at fairs. Central locations are not only beneficial for exhibitors to receive more attention, but it also enables them to be close to major firms.

Our observations open some avenues for further research. Firstly, we suggest analyzing the contribution of other types of city festivals for generating sustainable competitiveness. Particularly, we suggest investigating art festivals, seen the role of artists in sustainable urban development (Kirchberg and Sagan, 2013 [17]). Likewise, more research attention is needed for analyzing sustainable competitiveness and events in other types of cities. Stagnated industrial cities use events as tools for image improvement and the development of new sectors (Garcia, 2005 [24]; Richards and Palmer, 2010 [1]), hence, mainly referring to the economic pillar of sustainable competitiveness, but how do more advanced cities use events in urban development strategies? It might be that such cities use events to also pay attention for societal and environmental development. Finally, further development of the concept of sustainable competitiveness is desired. Currently, the concept is mainly based on urban management literature. Including insights from other fields, sociology and environmental studies in particular, could help to strengthen the concept further.

Despite this specific case study, and its results can not be generalized, it is possible to draw some general lessons that may be used by other cities that want to use annual city festivals as tools for generating sustainable competitiveness. First of all, rather than copying events from elsewhere (e.g., following hypes like "Oktober Fests" or Christmas markets), it is wise to organize an event that is linked with the city's economic structure and society. The WPD is directly linked with Rotterdam's major economic pillar and is organized by local stakeholders. However, here also lays a major challenge for the WPD, as in times of globalization, the local port community gets smaller and many firms in the port are foreign owned, making participation less straightforward than in the past. Secondly, in order to use events for societal and business development, it is crucial to search common opportunities or challenges. The WPD is a major tool to explain the port and industrial activities to society and to counter the negative effects caused. Both the Port Authority and the City Government, as well as the business society, agree about the relevance of the event to communicate with society that is needed to develop the port and industrial cluster further. Thirdly, it is important to keep the core, but also to adapt events according to changes in society and the industry. The original ratio of the WPD-to show the port to the citizens-is still the major ratio to organize the event and to participate, despite 
changes in the concept and organization of the event in time. Currently, the organizer of WPD attempts to renew the event again by increasing the use of social media, and by making it more international (referring both to participants as well as to visitors). Finally, an important aspect of the educational role of events is "infotainment", combining spectacle and doing with learning and information. The WPD combines presentations, lectures and seminars with demonstrations and excursions in which visitors can experience the port (e.g., via boat trips and the use of cranes and other equipment). "Learning by playing" seems to be an important ingredient to inform the citizens about the port.

Author Contributions: Both authors contributed equally.

Conflicts of Interest: The authors declare no conflict of interest.

\section{References}

1. Richards, G.; Palmer, P. Why cities need to be eventful. In Eventful Cities: Cultural Management and Urban Revitalisation; Butterworth-Heinemann: Oxford, UK, 2010; Chapter 1, pp. 1-38.

2. Linko, M.; Silvanto, S. Infected by Arts Festivals: Festival Policy and Audience Experiences in the Helsinki Metropolitan Area. J. Arts Manag. Law Soc. 2011, 41, 224-239.

3. Maskell, P.; Bathelt, H.; Malmberg, A. Building global knowledge pipelines: The role of temporary clusters. Eur. Plan. Stud. 2006, 14, 997-1013. [CrossRef]

4. Lampel, J.; Meyer, A.D. Field-Configuring Events as Structuring Mechanisms: How Conferences, Ceremonies, and Trade Shows Constitute New Technologies, Industries, and Markets. J. Manag. Stud. 2008, 45, 1025-1035. [CrossRef]

5. Carvalho, L.; van Tuijl, E.; van den Berg, L. A World of Events: How Can Cities Anchor the Advantage? Euricur: Rotterdam, The Netherlands, 2012.

6. Quinn, B. Arts festivals and the city. Urban Stud. 2005, 41, 927-942. [CrossRef]

7. Van Aalst, I.; van Melik, R. City festivals and urban development: Does place matter? Eur. Urban Reg. Stud. 2011, 18, 1-12. [CrossRef]

8. Nijdam, M.N.; Bakker, D.; van der Lugt, L. The Economic Value of Dutch Sea Ports; RHV—Erasmus University Rotterdam: Rotterdam, The Netherlands, 2012.

9. Van den Berg, L., van der Meer, J., Carvalho, L. (Eds.) Cities as Engines of Sustainable Competitiveness: European Urban Policy in Practice; Ashgate: Aldershot, UK, 2014.

10. Carvalho, L.; van den Berg, L.; Gala, H.; Teunisse, P. Delivering Sustainable Competitiveness, Revisiting the Organising Capacity of Cities; Routledge: Abingdon, UK, 2016.

11. Van Tuijl, E.; van den Berg, L. Climate Adaptation as Source for Sustainable Competitiveness: The Venice Experience. In Proceedings of the XIV International Forum on Urban Competitiveness, Queretaro, Mexico, 24-25 August 2015.

12. Camagni, R.; Capello, R.; Nijkamp, P. Towards sustainable city policy: An economy-environment technology nexus. Ecol. Econ. 1998, 24, 103-118. [CrossRef]

13. Hopwood, B.; Mellor, M.; O’Brien, G. Sustainable development: Mapping different approaches. Sustain. Dev. 2005, 13, 38-52. [CrossRef]

14. WCED. Our Common Future; Oxford University Press: Oxford, UK, 1987.

15. OECD Sustainable Development. Linking Economy, Society and Environment; OECD Publishing: Paris, France, 2008.

16. Van den Berg, L.; Jacobs, W.; Nijdam, M.; van Tuijl, E. Sustainable development of cities: The role of leader firms. In Cities and Partnerships for Sustainable Urban Development; Kresl, P.K., Ed.; Edward Elgar Publishing: Cheltenham, UK, 2015.

17. Kirchberg, V.; Kagan, S. The roles of artists in the emergence of creative sustainable cities: Theoretical clues and empirical illustrations. City Cult. Soc. 2013, 4, 137-152. [CrossRef]

18. Porter, M.E. Location, competition, and economic development: Local clusters in a global economy. Econ. Dev. Q. 2000, 14, 15-34. [CrossRef]

19. Kresl, P.; Ietri, D. Urban Competitiveness: Theory and Practice; Routledge: Abingdon, UK, 2014.

20. Malecki, E. Jockeying for position: What it means and why it matters to regional development policy when places compete. Reg. Stud. 2004, 38, 1101-1120. [CrossRef] 
21. Rodríguez-Pose, A.; Arbix, G. Strategies of waste: Bidding wars in the Brazilian automobile sector. Int. J. Urban Reg. Res. 2001, 25, 134-154. [CrossRef]

22. Van den Berg, L.; Braun, E.; van der Meer, J. Metropolitan Organising Capacity_Experiences with Organising Major Projects in European Cities; Euricur series; Alshgate: Aldersschot, UK, 1997.

23. Porter, M.E.; Kramer, M.R. Creating shared value. Harv. Bus. Rev. 2011, 89, 62-77.

24. Garcia, B. Deconstructing the city of culture: The long-term cultural legacies of Glasgow 1990. Urban Stud. 2005, 42, 841-868. [CrossRef]

25. Gotham, K.F. Resisting Urban Spectacle: The 1984 Louisiana World Exposition and the Contradictions of Mega Events. Urban Stud. 2011, 48, 197-214. [CrossRef]

26. Bathelt, H.; Schuldt, N. Between luminaries and meat grinders: International trade fairs as temporary clusters. Reg. Stud. 2008, 42, 853-868. [CrossRef]

27. Power, D.; Jansson, J. Cyclical clusters in global circuits: Overlapping spaces in furniture trade fairs. Econ. Geogr. 2008, 84, 423-448. [CrossRef]

28. Borghini, S.; Golfetto, F.; Rinallo, D. Ongoing search among industrial buyers. J. Bus. Res. 2006, 59, 1151-1159. [CrossRef]

29. Roche, M. Mega-events and urban policy. Ann. Tour. Res. 1994, 21, 1-19. [CrossRef]

30. Getz, D. Event tourism: Definition, evolution and research. Tour. Manag. 2008, 29, 403-428. [CrossRef]

31. Van der Wilt, G.H. Recreational City Visits by Inhabitants of Rotterdam 2003-2009; COS: Rotterdam, The Netherlands, 2011. (In Dutch)

32. Reijnen, A. Image Festivals in Rotterdam; COS: Rotterdam, The Netherlands, 2011. (In Dutch)

33. Nijdam, M. Local effects of global trends: Internationalisation of port-industries and its effect on port clusters, the case of Rotterdam. In Proceedings of the IAME Conference, Copenhagen, Denmark, 24-26 June 2009.

34. Gotham, K.F. Marketing Mardi Gras: Commodication, Spectacle and the Political Economy of Tourism in New Orleans. Urban Stud. 2002, 39, 1735-1756. [CrossRef]

35. Johansson, M.; Kociatkiewicz, J. City festivals: Creativity and control in staged urban experiences. Eur. Urban Reg. Stud. 2011, 18, 392-405. [CrossRef]

(C) 2016 by the authors; licensee MDPI, Basel, Switzerland. This article is an open access article distributed under the terms and conditions of the Creative Commons Attribution (CC-BY) license (http://creativecommons.org/licenses/by/4.0/). 